
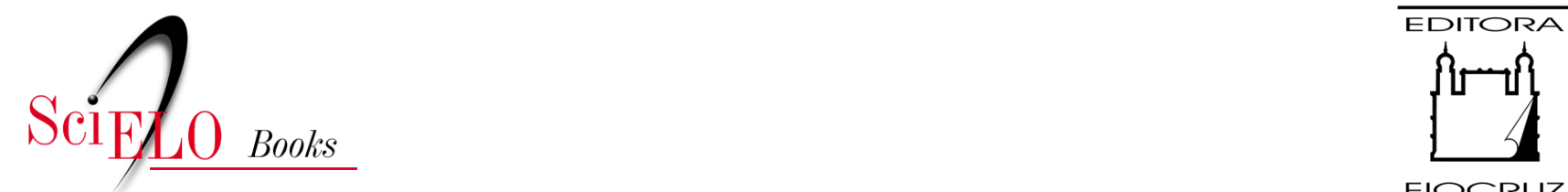

FIOCRUZ

\title{
De Medicina Preventiva à medicina baseada em evidências
}

\author{
Gastão Wagner de Sousa Campos
}

\section{SciELO Books / SciELO Livros / SciELO Libros}

CAMPOS, G.W.S. De Medicina Preventiva à medicina baseada em evidências. In: AROUCA, S. $O$ dilema preventivista: contribuição para a compreensão e crítica da medicina preventiva [online]. Rio de Janeiro: Editora FIOCRUZ, 2003, pp. 215-217. ISBN: 978-85-7541-610-5. Available from: doi: $10.7476 / 9788575416105.0019$. Also available in ePUB from: http://books.scielo.org/id/q7gtd/epub/arouca-9788575416105.epub

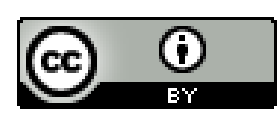

All the contents of this work, except where otherwise noted, is licensed under a Creative Commons Attribution $\underline{4.0 \text { International license. }}$

Todo o conteúdo deste trabalho, exceto quando houver ressalva, é publicado sob a licença Creative Commons Atribição 4.0. 


\section{De Medicina Preventiva à medicina baseada em evidências}

\section{Gastão Wagner de Sousa Campos ${ }^{1}$}

Inquietação teórica e prática diante da vida. Inconformismo com a injustiça. Audácia e coragem para apostar no novo. Capacidade para lidar com contradições. Liderança. Assim foi Sérgio Arouca. Assim é sua tese de doutorado $O$ dilema preventivista.

Quando esse trabalho foi elaborado estávamos na metade dos anos 70. E já naquele então, Arouca, sem abandonar sua tradição crítica, reconhecia a insuficiência do Materialismo Histórico - particularmente daquele fossilizado e grafado, assim, em letras maiúsculas - para explicar o que vinha acontecendo na saúde. $\mathrm{Na}$ busca de um esquema conceitual que lhe permitisse uma análise mais aguçada do contexto, ele procedeu a uma fusão inovadora de elementos do materialismo histórico com a arqueologia recentemente elaborada por Michel Foucault. Ainda me recordo de um diálogo áspero entre Arouca e um marxista ortodoxo. Este o interpelou e o repreendeu por misturar conceitos, segundo ele, absolutamente antagônicos. Arouca respondeu-lhe de maneira precisa e cortante, perguntandolhe se ele discordava do produto, se ele não reconhecia a relevância do trabalho elaborado. O senhor, se desculpou, não, claro, o trabalho era útil e esclarecia o tema. Então, fulminou Sérgio, fiz bem em misturar Marx com Foucault.

Fiel a esse desafio, no Capítulo VI, ele procura desvendar as "regras da formação discursiva" da Medicina Preventiva. É impressionante a atualidade e a agudeza do seu método, e não resisto à tentação de estender suas análises sobre a medicina preventiva para um outro movimento ideológi-

1 Professor livre-docente da Faculdade de Medicina Preventiva da Universidade Estadual de Campinas. Secretário executivo do Ministério de Saúde. 
co, mais recente, em que a medicina, como naquela ocasião, busca sobreviver às mudanças sem perder suas características essenciais. Refiro-me ao movimento que ficou conhecido como "medicina baseada em evidências".

Primeiro Arouca investigou a "formação do objeto da medicina preventiva". Com simplicidade e argúcia ele descobriu uma tentativa da medicina preventiva de separar-se (diferenciar-se) e, ao mesmo tempo, identificar-se com a medicina tradicional por meio de uma adjetivação da mesma. O "preventivo" agregado sintetizava uma intenção, um esforço para indicar uma possibilidade de transformação que interessaria à ciência e à prática profissional. A expressão "baseada em evidência" repete, décadas depois, o mesmo estratagema.

A "medicina baseada em evidências", apoiando-se na estatística e na epidemiologia clínica, significaria uma reforma radical do saber e da prática médica, conseguindo graças a esses novos procedimentos superar uma série de fatos negativos que estariam ameaçando a hegemonia da biomedicina. A introdução deste novo discurso seria potente para regular a incorporação de tecnologia, evitaria a iatrogenia, procedimentos desnecessários e a má-prática em geral. Com a nova formação discursiva estaria assegurada a pureza da medicina, doravante, pelo menos em teoria, comprometida apenas com a eficácia de suas práticas.

Ao se fazer essa comparação, é de sentir até um pouco de saudade da "reforma" sugerida pela medicina preventiva. Esta pelo menos tentava modificar a medicina importando conceitos das ciências sociais, ainda que restritos a um funcionalismo duvidoso e reducionista. De qualquer forma, aquela reforma dos anos 70 declarava objetivos um pouco mais ousados do que estes do fim do século XX.

Outra estratégia usada por Arouca para compreender o movimento da Medicina Preventiva foi o de identificar seus centros de divulgação e seus modos de operar sobre o mundo. A medicina preventiva agiu com uma certa externalidade à medicina, a elaboração de suas teses e de seus projetos de intervenção dependeu de fundações, bancos e organismos internacionais que não pertenciam à instituição médica. Cientistas sociais e sanitaristas elaboraram as críticas e as receitas a serem seguidas pelas organizações médicas, faculdades, serviços etc. Posteriormente, logrou-se "infiltrar" a instituição médica por meio da criação dos Departamentos de Medicina Preventiva. A coisa não colou muito, afinal as estratégias de intervenção utilizadas poderiam ser consideradas ingênuas frente à resistên- 
cia do instituído. A "medicina baseada em evidências", ao contrário, é orgânica à medicina, foi criada e vem sendo divulgada por organismo do aparelho médico.

De qualquer maneira, como apontou Arouca, esses movimentos, ainda que padecendo de limitações, ainda que com um discurso de reforma que mascara sua intenção de conservar aquilo que deve ser transformado, terminam por levantar críticas pertinentes e, nessa medida, ajudam a ampliar o espaço daqueles comprometidos com transformações mais amplas. A medicina preventiva, dentro desta lógica, e em alguma medida, terminou por ser uma das bases de construção da reforma sanitária brasileira e do sUs. 